\title{
GNRHR wt Allele
}

National Cancer Institute

\section{Source}

National Cancer Institute. GNRHR wt Allele. NCI Thesaurus. Code C51454.

Human GNRHR wild-type allele is located in the vicinity of 4 q21.2 and is approximately 16 $\mathrm{kb}$ in length. This allele, which encodes gonadotropin-releasing hormone receptor protein, is involved in both the neuroregulatoion of reproduction and in the release of gonadotropic luteinizing hormone and follicle stimulating hormone. Defects in the gene are a cause of hypogonadotropic hypogonadism. 